\title{
The effect of a total rewards strategy on school teachers' retention
}

\author{
Authors: \\ Boitomelo Makhuzeni ${ }^{1}$ \\ E. Nicolene Barkhuizen ${ }^{1}$ \\ Affiliations: \\ ${ }^{1}$ Department of Industrial \\ Psychology, North-West \\ University, Mafikeng Campus, \\ South Africa \\ Correspondence to: \\ Nicolene Barkhuizen \\ Email: \\ nicolene.barkhuizen@nwu. \\ ac.za \\ Postal address: \\ Private Bag X2046 \\ Mmabatho 2745, \\ South Africa \\ Dates: \\ Received: 06 Mar. 2015 \\ Accepted: 21 Aug. 2015 \\ Published: 05 Nov. 2015 \\ How to cite this article: \\ Makhuzeni, B., \& Barkhuizen, \\ E.N. (2015). The effect of \\ a total rewards strategy \\ on school teachers' \\ retention. SA Journal \\ of Human Resource \\ Management/SA Tydskrif vir \\ Menslikehulpbronbestuur, \\ 13(1), Art. \#699, 10 pages. \\ http://dx.doi.org/10.4102/ \\ sajhrm.v13i1.699

\section{Copyright:} \\ C 2015. The Authors. \\ Licensee: AOSIS \\ OpenJournals. This work is \\ licensed under the Creative \\ Commons Attribution \\ License.
}

\section{Read online:}

Orientation: South African schools are facing significant challenges to retain a talented pool of school teachers. A total rewards strategy could assist schools to reduce teacher turnover.

Research purpose: The aim of this study was to determine the effect of a total rewards strategy on the turnover intentions of school teachers in the North-West province.

Motivation: The under supply of quality teachers has negative consequences for both school pupils and the larger community.

Research approach, design and method: A qualitative research approach was followed using semi-structured interviews to gather data from teachers in the North-West province $(N=6)$.

Main findings: The findings showed that performance management, career development and compensations of teachers were poorly applied in schools. Teachers strongly considered leaving the teaching profession as a result of poor rewards. The participants were fairly satisfied with their work benefits and work-life balance.

Practical/managerial implications: School management should implement reward practices and policies that will attract and enhance retention of school teachers.

Contribution: This research highlighted the problematic areas in the reward systems for school teachers and the subsequent impact thereof on their turnover intentions.

\section{Introduction}

The retention of quality teachers is a major problem in South African schools (Steyn, 2013). Factors contributing to the shortage of educators include resignation, medical boarding, dismissal, emigration of highly trained professionals for greener pastures and restrictions related to self-development and a lack of recognition for good performance (Adedeji \& Olaniyan, 2011; Schullion, 2011). In particular, teachers are constantly protesting as a result of the poor remuneration and reward practices (Armstrong, 2007). As a result of these factors teachers are leaving the teaching profession for better compensation in developed countries or other career prospects (South African Council for Educators, 2010). Teacher turnover leads to a significant loss of service efficiency which eventually has a detrimental effect on the performance of school children (Williams, Champion \& Hall, 2012).

The task of the Department of Education is, therefore, to develop attractive reward and remuneration practices that will retain a talented pool of school teachers (Armstrong, 2009; SACE, 2010). According to Shukia (2009) effective reward and retention policies improve teacher abilities and the school's overall effectives. Retention policies should be able to attract new employees, satisfy the older generation of employees and motivate current employees to stay within the organisation (Barkhuizen, 2014). One of the best methods that institutions can implement to retain employees is to adopt good remuneration practices (Davis \& Edge, 2004; Gerhart \& Rynes, 2003).

The main objective of this research was to determine the effect of reward and remuneration practices on the retention of school teachers in the North-West province. More specifically this research addressed the following research questions:

- What are teacher's perceptions of the current state of rewards in the teaching profession?

- To what extent do rewards influence teachers' decisions to leave the teaching profession?

This research is motivated by the fact that the Global Competitiveness Report continues to rank South Africa as poor in terms of people development (Schwab, 2015). This is a consequence of a poor schooling system that fails to deliver scholars with the necessary skills and competencies to add value to the country as whole (Dieltiens \& Meny-Gibert, 2012). This research is further 
motivated by the fact that quality school teachers are becoming a scarce resource within developing countries which in turn has a negative impact on the overall school performance (Bartlett, 2011; Ruchi \& Justin, 2014).

A recent report by the North-West Provincial Legislature (2013) pointed out that the allocation of teachers at schools is a major challenge. The significant shortage of teachers had a profound impact on the performance and pass rate of grade 12 learners. Other problems highlighted included:

- some teachers absconding from their duties to leave learners unattended

- service delivery protests that led to the poor attendance of learners

- School Governing Bodies that are not functioning well

- teenage pregnancy

- a lack of resources such as water and sanitation at schools

- scholar transport problems.

In addition to these a study by Leke-ateh, Assan and Debeila (2013) showed that teacher trainees are not adequately prepared for teaching practice, mentors are not sufficiently involved in teaching practice because they lack knowledge of mentorship, and the assessment and awarding of teaching practice marks are subjective. We believe that this research will make an important contribution towards highlighting the reward factors that will retain quality school teachers in a developing context such as South Africa.

\section{Literature review Total rewards}

Total compensation systems aim to achieve multiple goals, including:

- attracting employees

- retaining solid perfomers

- motivating perfomance

- spending compensation money wisely

- aligning employees with organisational goals

- rewarding the behaviour that the organisation wants to encourage (Reddick \& Coggburn, 2008).

For the purposes of this research we used the Total Rewards Model of the World at Work Society as a framework to explore teachers' perceptions of rewards in the workplace. The World at Work Society (2011), for professionals, developed and validated a total rewards model to reflect the strategic elements of the employer-employee exchange and how it affects the attraction, motivation, retention and engagement of employees. According to this model the total rewards strategy of an organisations should consist of the following five practices:

- Compensation - The fix of variable pay provided to employees by the employer for services rendered.

- Benefits - The programs an employer can use such as health, income protection and retirements benefits to provide security for employees and their families and supplement the cash component that employees receive.
- Work-life Balance - The organisational support structures that enable employees to achieve success both in the workplace and at home.

- Performance management - The alignment of employee efforts towards the achievement of business goals and effectiveness.

- Career development-The opportunities and mechanisms for employees to advance their skills and competencies in their future careers.

Nthebe (2015) recently applied the total rewards model to a sample of school principals in the North-West province. The results showed that total rewards were a significant predictor of well-being and service orientation of school principals. This study, furthermore, proved that the total rewards model is applicable for use in the public sector domain as well.

Remuneration: Remuneration can be demarcated into compensation and incentives. Employees are remunerated when an income or other financial benefits are allotted to them for service rendered (Baguiley, 2009). The pay arrangement regulates what an employee is paid once the job has been assessed on its virtual worth. The organisation governs the pay construction and the pay rankings for jobs of comparable significance and complexities (Barkhuizen, 2011). Organisations are now discovering the necessity to cultivate tailor-made compensation practices to reward the exclusive critical skills of gifted employees (Schlechter, Faught \& Bussin, 2014). In a highly globalised setting, it is obligatory to have extremely flexible and customised compensation strategies to reward exceedingly skilled employees. Organisations are under growing pressure to develop aptitude and skills related pay for inspiring employees to advance their knowledge, skills and abilities on a continuous basis (Durai, 2010).

The available research clearly points out that teachers are poorly compensated and underpaid (see Correa, Parry \& Reyes, 2015; Qureshi, 2015; Smith, Conley \& You, 2015). Krueger (2002) maintains that public revenue must be used justifiably to fund public schools, including teachers' salaries, which must be wholly paid by the government. Although the post-apartheid equalisation of teacher pay initially resulted in a substantial increase in teacher salaries, evidence suggests that salary increases during the past decade plateaued to the extent that teachers are not able to match their cost of living (Armstrong, 2009; Strauss, 2012). Research by van der Berg and Burger (2010) found that financial incentives for South African teachers are limited as a result of fiscal constraints. A study by Rothstein (2015) showed that teacher tenure can only be accomplished by large increases in salaries.

Benefits: Beam and McFadden (2001) refer to benefits as the financial or non-financial payments that employees receive for continuing their employment with the company. Benefits include employer-provided benefits for death, accident, sickness, retirement or unemployment. Fringe benefits are a collection of numerous benefits delivered by an employer, which are exempt from taxation (Berger \& Berger, 2008). 
Fringe benefits commonly include health insurance, group term life coverage, education reimbursement and other related benefits (Armstrong \& Murlis, 2007).

According to a report by SACE (2010) teachers regarded non-financial rewards such as employer brand, working hours, and holidays as important factors that will attract and retain them in the teaching profession. Teachers furthermore regarded sense of community, personal connectedness and the opportunity to make a difference to school children (Müller, Alliata \& Benninghoff, 2009) as important benefits in the teaching profession. Strauss (2012) found similar results in a sample of school teachers in South African rural schools.

Work-life Balance: Work place flexibility attracts skilled and motivated employees (Disselkamp, 2013). Flexibility can further improve customer service and retention, more committed employees and greater employee retention (Christensen \& Schneider, 2010; Maitland \& Thomson, 2011).

Various studies to date explored the factors that enhance the work-life balance of teachers. The results showed that teachers with high levels of emotional intelligence and who are satisfied with their pay experience less work-family conflict (see Kappagoda \& Sampath, 2014; Khokhar \& Ziaur-Rehman, 2014). Strauss (2012) found that family support and work-life excellence are key motivators to retain teachers in rural schools. A study by Vorster and Barkhuizen (2013) indicated that support from both the family and work context are essential to maintain a balanced work and personal life. Hudson (2012) highlighted the importance of willing and capable assigned mentors who can model practices and provide feedback on beginning teacher's practices to enable them to maintain a healthy work-life balance.

Miryala and Chiluka (2012) pointed out the importance of work-life balance policies and programmes that enable the teaching community to balance their work and personal life needs. Padma, Reddy and Sudhir (2014) further mention that work-life balance facilities are important tools to attract and retain a talented pool of school teachers. Clearly then a supportive work environment is important to assist teachers in managing their multiple roles and, at the same time, results in lower attrition rates (Chawla \& Sondhi, 2011).

Performance and Recognition: A good performance management system can act as a positive method to identify developmental opportunities and implement succession planning processes (Mondy, Noe \& Premeaux, 2002). Performance appraisals are useful mechanisms to improve employee performance, within the educational field (Steinberg, 2014; Tuytens \& Devos, 2012).

The performance management systems in many schools, however, are subjected to intense scrutiny as teachers are being held accountable for the performance of learners (Monyatsi, Steyn \& Kamper, 2006). The Education Labour
Relations Council introduced the Integrated Quality Management System (IQMS) in 2003 to assess amongst others the performance of school teachers (Mosoge \& Pilane, 2014). The findings of Mosoge and Pilane indicate that the lack of knowledge and expertise on the IQMS processes such as mentoring, coaching, and monitoring hampers the effective implementation of performance management. Consequently teachers are being blamed by management for poor school performance who are also ignoring the failures of control systems or broader systematic issues.

Day (2012) found that poor performance management systems in schools resulted in destabilisation, increased workload, intensification of work, a crisis of professional identity for many teachers and a subsequent loss of public confidence and service quality. According to Briere, Simonsen, Sugai and Myers (2015) constructive performance feedback is important to retain younger teachers in the profession. A study by Tuytens and Devos (2012) showed that the extent to which teachers are allowed to participate in the performance appraisal system significantly influences their perceptions of procedural fairness and usefulness of performance feedback.

Recognition for performance is an important factor to enhance employee morale (Smithe \& London, 2009). High employee morale reduces stress, absenteeism and turnover and increases employee performance (McCleod, 2010). Research showed that enhanced performance recognition motivates teachers to advance their careers (Patton \& Parker, 2015). Non-recognition for performance, however, reduces the quality teaching of school children (Hanhela, 2014). Educators, therefore, should receive regular feedback on their own performance as well as recognition for a job well done (Williams et al., 2012).

Career Development: The importance of career development of school teachers is widely documented. The development of school teachers can result in several positive outcomes such as:

- increased work identity (Du Plessis, Carroll \& Gillies, 2015)

- enhanced quality of interaction with school children (Pianta et al., 2014)

- animproved teaching climate(Avidov-Ungar,Friedman \& Olshtain, 2014)

- self-efficacy and confidence (Chia-Pin, Chin-Chung \& Meilun, 2014)

- collaboration skills (Morel, 2014).

Employers can contribute significantly to their staff members' career development by supporting career development activities within the department (Foskett \& Lumby, 2002). Schullion (2011) is of the opinion that the Department of Education can motivate and retain educators by providing them with other career path opportunities to occupy senior positions based on good performance and proven managerial skills. 
Applied within the South African context teachers in rural areas are limited in terms of career development opportunities (Strauss, 2012). Career development opportunities are important factors that attract younger generations to organisations (Barkhuizen, 2014). The high turnover rate of quality younger teachers results in teaching becoming an ageing profession (Armstrong, 2007). The Department of Education, therefore, has to invest in career development programmes to attract and retain quality school teachers.

\section{Research design Research approach}

A qualitative research approach using semi-structured interviews based on the framework of the total rewards strategy was used. According to Pring (2004) qualitative research seeks to understand a given research problem or topic from the perspectives of the local population that it involves. In broad terms qualitative research is an approach that allows one to examine people's experiences in detail (Hennink, Hutter \& Bailey, 2011). Qualitative data are organised, interpreted, analysed and communicated so as to address real world concerns (Tracy, 2013).

\section{Research strategy}

A case study strategy was applied for this research. A case study strategy was deemed most appropriate as the researchers aimed to investigate a contemporary phenomenon in the real-life context (Cresswell, 2009). More specifically this research followed a multiple case study design which included several cases as a unit of analyses, in this case it was teachers (Yin, 2012). The themes were derived from the semi-structured interviews and were compared with the relevant literature to generate a universal result.

\section{Research setting}

The research setting included two samples. The first sample included three teachers who were employed in public schools in the Mafikeng are of the North-West province. The second sample included three teachers who were previously employed in the North-West provincial schools but who left the teaching profession for other research opportunities. The latter participants were also situated in the Mafikeng area. The participants were interviewed at their offices for the sake of convenience, so that they could feel comfortable and to ensure privacy.

\section{Research method \\ Entrée and establishing researcher roles}

Permission was requested from the Head of the Department of Education in the North West province to enter schools in the North West province. Once approval was obtained, school principals were approached for permission to conduct the research, which was granted. Ethical approval was obtained from North-West University prior to the execution of the research. Confidentiality was maintained at all times.

\section{Sampling}

The unit of analysis for this study was North West province schools. Six participants were selected on a purposive convenience basis to participate in the study. Three of the participants were still employed as teachers at the time of the interviews and three had left the profession for other career opportunities. All of the participants could give an account of the reward system of the schools. An equal number of males and females participated in this research. All of the participants were representative of the African ethnic group. Five of the participants were in possession of a Degree and had more than ten years of teaching experience.

\section{Data collection method}

The data were collected through semi-structured interviews, in which the researcher prepares a list of themes and questions to be covered during the interview (Saunders, Lewis \& Thornhill, 2007). The number, order and nature of questions vary from one interview to the next, and are dependent on the context and situation within which the interview takes place. According to Bless, Higson-Smith and Kagee (2006), qualitative interviewing has a unique advantage as a result of its specific form. The researcher has the opportunity to learn about other elements related to the topic, about which the researcher would otherwise be unaware. The researcher also receives the opportunity to hear the participants view concerning the factors of focus in the study. The interviews were conducted in English. The questions were based on the total rewards framework of the World at Work Society (2011). The teachers were asked to indicate how they experience and have experienced the five rewards practices as specified in this model. The questions were phrased to determine whether these rewards will influence them or have influenced them to leave the teaching profession.

\section{Recording of data}

As qualitative research produces a considerable amount of data it became imperative to ensure the easy retrieval of data for later detailed analysis. To support this method of data collection, audio recordings and transcriptions were taken and deemed to be appropriate. In addition, notes were taken during the interviews to provide information concerning the participants' non-verbal communication. Verbatim transcriptions were transcribed of the data.

\section{Data analyses}

According to Bryman and Bell (2012) qualitative analyses begin in the field as researchers identify problems during observations and interviewing. Theme (content) analyses were applied to analyse and interpret the data. The analyses started with a process for organising the data that were collected (Thyme, Wiberg, Lundberg \& Graneham, 2013). Thereafter the data were systematically analysed to identify the themes and sub-themes. Cooper and Schindler (2011) 
maintain that theme analyses prevent selective perception of the content and ensure reliability and validity in qualitative research.

\section{Ensuring the quality and rigour of the research}

Data verification is a process where different types of data are tested for accuracy and inconsistencies after data migration is completed (Morse \& Niehaus, 2009). The trustworthiness of a qualitative study was ensured by maintaining high credibility and objectivity (Stempien \& Loeb, 2002). As a qualitative researcher's perspective is naturally biased as a result of the researcher's association with the data, sources, and methods, various audit strategies were used to confirm findings. The data transcriptions were returned to participants to verify the accuracy of the statements. Peer debriefing was also applied. These methods enhanced the trustworthiness of interpretations and findings (Bamberger, 2000).

\section{Reporting}

The findings of this research are reported in table format. The themes and sub-themes extracted from the interviews are substantiated by direct quotes. This method conforms with the modernistic qualitative research approach where the researcher seeks for support that a conclusion applies in a specific research context (Cresswell, 2009).

\section{Findings}

Table 1 presents the themes that emerged from the focus group sessions. The table gives the frequency with which themes emerged. The researchers identified 15 themes from the combined responses of the participants. Table 1 shows that 'availability of leave opportunities (i.e. sick, holiday, study)', 'lack of recognition for performance' and 'lack of career advancement opportunities' were the themes that occurred most often.

The themes were further clustered into the five main categories of rewards based on the frequencies of the

TABLE 1: Themes deduced from the participants.

\begin{tabular}{ll}
\hline Themes & $\boldsymbol{F}$ \\
\hline Availability of leave opportunities (i.e. sick, holiday, study) & 19 \\
Lack of recognition for performance & 11 \\
Lack of career advancement opportunities & 11 \\
Support from family & 10 \\
Poor performance management & 8 \\
Flexible work & 7 \\
Management and collegial support & 7 \\
Poor Salaries & 5 \\
Contribution to child development & 5 \\
Unfair promotion practices & 5 \\
Salaries do not match cost of living & 5 \\
Teaching experience for career advancement & 5 \\
Qualifications for career advancement & 4 \\
Unclear Performance Targets & 3 \\
Poor preparation for career changes & 3 \\
\hline
\end{tabular}

sub-themes. Combined themes in this study were mostly related to performance management. Remuneration appeared to be the least important theme in this study. The main themes and sub-themes are presented in Table 2. This article discusses the themes according to the framework presented in the literature review.

\section{Theme: Performance management and recognition}

Combined, the themes relating to performance management and recognition occurred mostly in this study. The lack of recognition for performance was one of the sub-themes that was mentioned second most often in this study (11 times). The participants in particular discussed how teachers are never recognised for good performance which in turn lowered their morale. Some of the participants mentioned the following:

'Definitely the Department did not recognize teachers ... I am one of them who produced the best results in English in the sachet around Rustenburg ... no recognition at all'. (Participant 4, Male, Master's Degree, resigned teacher, eight years working experience in the teaching profession)

\section{Participant 2 supported this view by adding:}

'In terms of recognition teachers aren't getting that much recognition ... most of the time you find that is the learners'. (Participant 2, Female, Master's Degree, teacher, 23 years working experience in the teaching profession)

The findings revealed that the participants were generally dissatisfied with the performance management of teachers (eight times). The participants indicated that whilst they were teachers no performance management system existed. As mentioned by one of the participants:

'What can I say about this performance management system by then there was no performance management system'. (Participant 5, Female, Bachelor's Degree, resigned teacher, three years of work experience in the teaching profession)

In support Participant 4 added:

'There were not policies that outlined performance in schools. There was no guidance'. (Participant 4, Male, Master's Degree, resigned teacher, eight years working experience in the teaching profession)

The participants also had reservations about the performance targets and were of the opinion that they are not achievable:

'According to them they say these standards are attainable but however at some point it does not it does not work with us'. (Participant 1, Female, Bachelor's Degree, teacher, four years working experience in the teaching profession)

\section{Theme: Benefits}

The sub-themes relating to benefits occurred second most in this study. Generally the participants appeared to be satisfied with the benefits offered by the teaching profession. 
TABLE 2: Categories of main and sub-themes.

\begin{tabular}{|c|c|c|c|}
\hline Main Theme & Sub-Themes & $\boldsymbol{F}$ & Total \\
\hline \multirow[t]{4}{*}{ Performance Management and Recognition } & Lack of recognition for performance & 11 & 27 \\
\hline & Poor performance management & 8 & \\
\hline & Unclear Performance Targets & 3 & \\
\hline & Unfair promotion practices & 5 & \\
\hline \multirow[t]{2}{*}{ Benefits } & Availability of leave opportunities (i.e. sick, holiday, study) & 19 & 26 \\
\hline & Contribution to child development & 7 & \\
\hline \multirow[t]{3}{*}{ Work-life Balance } & Support from family & 10 & 24 \\
\hline & Flexible work & 7 & \\
\hline & Management and collegial support & 7 & \\
\hline \multirow[t]{4}{*}{ Career Development } & Lack of career advancement opportunities & 11 & 23 \\
\hline & Teaching experience for career advancement & 5 & \\
\hline & Qualifications for career advancement & 4 & \\
\hline & Poor preparation for career changes & 3 & \\
\hline Remuneration & Poor Salaries & 5 & 10 \\
\hline
\end{tabular}

The availability of various leave benefits such as study leave, vacations and sick leave were the themes that occurred mostly in this study (19 times). Participant three explained this theme as follows:

'I can say all this benefits work for me especially sick leave, study leave and paid public holidays because with study leave I can be able to study and obtain more qualifications ...'. (Participant 3, Male, Bachelor's Degree, Teacher, four years of work experience in the teaching profession)

Another participant added:

'I would say the ones that best suited me were public holidays in a sense that I was staying away from my family and so public holidays, paid public holidays were giving me time to go meet my family'. (Participant 4, Male, Master's Degree, resigned teacher, eight years working experience in the teaching profession)

The participants indicated that one of the reasons they are still in the teaching profession is because of the fact that they can make a contribution to a child's life. The participants who left the profession also highlighted that child development is a positive aspect of teaching. One of the participants mentioned:

'When you teach the kid you are helping the nation. You are giving skills to children ... you are empowering them to be good citizen, to be skilled workers for the future one day. You are laying a foundation for something good in the future that is the only advantage because the nation must be educated'. (Participant 6 , Male, Matric plus teaching Diploma, resigned teacher, four years of working experience in the teaching profession)

Another participant added:

'For me the advantage of teaching is that you get to work with young minds you know the good thing is having to you also had a hand in building the child to be something nice in life'. (Participant 2, Female, Master's Degree, teacher, 23 years working experience in the teaching profession)

\section{Theme: Work-life balance}

Work-life balance was the theme that was mentioned the third most in this study based on the sub-themes derived from the participants' responses. The participants highlighted that family support for their work enabled them to meet work and personal life demands. As mentioned by one of the participants:

'My family of course they are always there for me they encourage me to go on and on when I want to quit'. (Participant 1, Female, Bachelor's Degree, teacher, four years working experience in the teaching profession)

Another participant added:

'From my family I receive lot of support ... They understand being a teacher there is many challenges that you need deal with'. (Participant 2, Female, Master's Degree, teacher, 23 years working experience in the teaching profession)

Management support from school principals was also highlighted as a contributing factor to the work-life balance of teachers. Some participants mentioned:

'In terms of the profession we have subject advisors, we have colleagues who are on our side ... we got principals who always take care of us ... so in my school there is so much support and the department they do visit us for the support'. (Participant 1 , Female, Bachelor's Degree, teacher, four years working experience in the teaching profession)

Participant 4 also highlighted the importance of management support:

'The principal were I started working ... he was a real leader ... he is the one who kept me in the profession ... he was like a father to me'. (Participant 4, Male, Master's Degree, resigned teacher, eight years working experience in the teaching profession)

\section{Theme: Career development}

The sub-themes relating to career development were the fourth most important for this study. The participants in general highlighted the lack of career development opportunities for teachers. This sub-theme occurred second most in this study (11 times). The findings showed that the participants appeared to be dissatisfied with the career development opportunities for teachers. Participant two explained this as follows: 
'When it comes to advancement opportunities there aren't that many ... it is all about experience ..., experience if you don't have experience then you are not considered therefore you have to be a teacher maybe for 4 years or 5 years and that could assist in order to go to a higher level or post rather than that you will still be in the same position'. (Participant 2, Female, Master's Degree, teacher, 23 years working experience in the teaching profession)

Participants also highlighted unfair career advancement practices and favouritism. The participants highlighted that in order to advance you must be a relative of someone in the school in which you work, or you must be affiliated to a union and be very close to the leader of that union. As mentioned by one of the participants:

'Within the teaching profession there is the favoritism and advancement of opportunities ... you can't get a better post especially when you are new is better if you stayed there for a particular period and then favoritism, I don't like the way they are doing it. Ibelieve everybody deserve opportunity as everyone in there'. (Participant 3, Male, Bachelor's Degree, Teacher, four years of work experience in the teaching profession)

\section{Another participant added:}

'Talking about advancement opportunities this one is a very painful thing in a sense that is only union members who get promoted ... you have to be affiliated to unions and be very close to leaders of union to be able to get promotion ... there is no equality at all'. (Participant 4, Male, Master's Degree, resigned teacher, eight years working experience in the teaching profession)

According to participants, a career development plan exists in some schools and is absent in others; it all depends on the principal and how professional and organised he or she is. Other participants, especially those who are still in the profession, highlighted that in the current system a career development plan exists even though they feel it does not cater for the old teachers who are accustomed to the old system in which there was no career development plan. The respondents also indicated that teachers are not given sufficient time to familiarise themselves with new school curriculums. As mentioned by one of the participants:

'ah when it comes to teaching this career development plan it doesn't work for old teachers especially with the changes that are happening regularly it doesn't suit them at all because it doesn't help them to develop, can be able to deliver the best content to the learners'. (Participant 3, Male, Bachelor's Degree, resigned Teacher, four years of work experience in the teaching profession)

\section{Another participant added:}

'For sure Department of Education did not have any career development plan ... not at all ... I can say, teachers were not encouraged at all to go at reading'. (Participant 4, Male, Master's Degree, resigned teacher, eight years working experience in the teaching profession)

\section{Theme: Compensation}

The sub-themes relating to compensation were less frequently mentioned compared to the rest of the themes. However, the findings relating to the current compensation of teachers are deemed important. Most of the participants were in agreement that teacher payment is poor and not sufficient to cover their costs of living. Participant three described this theme as follows:

'I have considered quitting this profession because we don't get much recognition and reward on this profession and our salary is as little as we cannot do anything with it'. (Participant 3, Male, Bachelor's Degree, Teacher, four years of work experience in the teaching profession)

Those participants, who had already left the profession for other careers, mentioned that they could not cover most of their basic needs when they were still in the teaching profession. Participant one mentioned the following:

'We want changes if I have to speak for all of us ... the money is not enough it ... does not match with the standard of living'. (Participant 1, Female, Bachelor's Degree, teacher, four years working experience in the teaching profession)

The above sentiment was echoed by Participant 4 who stated:

'Unfortunately at that time the money was very little I struggled to meet my needs'. (Participant 4, Male, Master's Degree, resigned teacher, eight years working experience in the teaching profession)

\section{Discussion}

The main objective of this research was to investigate the effect of rewards on the retention of school teachers. More specifically this research aimed to investigate teachers' perceptions of the current rewards in the teaching profession. Furthermore this research aimed to investigate the extent to which rewards influence teachers' decisions to leave the teaching profession.

In this research we used the Total Rewards Model of the World at Work Society (2011) to determine the extent to which teachers experienced performance management, benefits, work-life balance, career development and compensation in their respective schools. The participants highlighted the lack of poor performance management systems in schools and specifically the lack of recognition for performance. The poor performance management system might be a consequence of the lack of understanding of the IQMS system (see Mosoge \& Pilane, 2014). Some of the participants highlighted the lack of performance guidance. The lack of performance policies and non-compliance with performance management systems can reduce teaching quality and service delivery (Hanhela, 2014; Smithe \& London, 2009). More concerning is that non-recognition for performance can result in increased absenteeism and eventually increased teacher turnover (McCleod, 2010).

The participants in this study seemed to be fairly satisfied with the benefits associated with the teaching profession. Most of the participants highlighted leave benefits (i.e. study, health and holiday) as important factors that will keep them in the teaching profession. These results confirm 
the findings of the SACE (2010) report that indicated that holiday benefits are an important retention factor for teachers. Teachers also mentioned the opportunity to work with children and make a contribution to their lives as a key factor that motivates them to remain in the teaching profession. The results are in line with previous studies which highlighted teacher-child interaction as an important teacher attrition factor (Strauss, 2012).

The findings showed that the participants are satisfied with their work-personal life balance. The participants mentioned that support from their families assisted them to deal more effectively with work demands (see Strauss, 2012). Management support from school principals was also a key factor that enabled the participants to manage work-family conflict. Several studies pointed out the importance of a supportive work environment in the attraction and attrition of school teachers (Hudson, 2012; Miryala \& Chiluka, 2012). Based on the above findings we can conclude that a healthy work-life balance is best achieved when employees are supported both from their work and family domains.

The findings of this research reemphasised the lack of career development opportunities in teaching (see Armstrong, 2007; Strauss, 2012). The results are concerning as the retention, especially of younger employees, depends on the availability of career development opportunities (Barkhuizen, 2014). Furthermore, teachers are also not able to benefit from the positive outcomes of career development (see Avidov-Ungar et al., 2014; Pianta et al., 2014) which in turn may hamper quality service delivery and teaching performance (Williams et al., 2012).

Finally, the findings showed that the compensation of teachers remains problematic. Most of the participants in this research were in agreement that teacher salaries are poor and prevent them from living a reasonable quality of life (see Correa et al., 2015; Qureshi, 2015; Smith et al., 2015; Strauss, 2012). Moreover, the findings clearly pointed out that the participants considered other career avenues as a consequence of poor remuneration (Davis \& Edge, 2004; Gerhart \& Rynes, 2003). In line with Rothstein (2015), school management needs to increase teacher remuneration as a measure to retain teachers.

To summarise, our findings showed that the factors that will contribute to teachers' turnover intentions include the lack of performance recognition, poor performance and rewards, no performance management system, no career advancement, no support from the profession and favouritism in terms of promotions. On the other hand our research also showed that the factors that will attract teachers to schools include flexible work, work-life balance, study leave, sick leave, child development and good leadership from the school principals. The future and sustainability of South Africa as a developing country is dependent on a good educational sector. Therefore, school managers are encouraged to develop appropriate reward policies and practices to create a healthy work environment that will secure a competent and skilled teacher workforce.

\section{Practical implications}

The findings of this research have important practical implications for the teaching profession. Although this research included a small sample, school management should take cognisance of problematic reward factors such as teacher compensation, performance management and recognition and career development, and implement corrective measures to retain quality school teachers.

The career development opportunities of teachers can also be enhanced. A career development plan should clearly outline the skills and knowledge that teachers need to enhance their careers, as well as outline how teachers can enhance the daily operations of the school and the expectation of the Department from teachers (Mosoge \& Pilane, 2014).

The findings of this research indicated that the Department of Education should consider developing the Department with more creative financial and non-financial rewards to attract and retain teachers. Furthermore teacher salaries need to be market related to ensure that they do not explore other career avenues.

\section{Limitations of the Study}

This research had some limitations. As a result of the small sample size the findings of this study are not generalisable to the general population. Firstly, the findings of this research study are only applicable to the specified area and cannot be expanded to the rest of the province or country. Secondly, the data were collected at one point in time which limits the research in terms of making a cause and effect relationship over a longer period of time.

\section{Recommendations for future research}

The results of this research provide various opportunities for future research. From a theoretical point of view the total rewards model can be expanded to include benefits for specific occupational domains such as teaching. The model can further be expanded to quantitatively assess and detect the effectiveness and organisational compliance with reward practices. Longitudinal studies can also be applied to test teacher perceptions of rewards over a longer period of time. Future studies should also focus on testing how reward practices differ between different generations based on their work experience. Future quantitative studies can benefit from testing total rewards with other outcome variables such as teacher performance. Finally, this study can also be expanded to other provinces in South Africa to compare total rewards practices at a national level. 


\section{Conclusion}

In conclusion, this research highlighted the importance of sound rewards and remuneration practices for the attraction and retention of teachers in the teaching profession. The Total Rewards Model of World at Work proved its utility as a framework to benchmark current teacher rewards. The findings of this research should encourage school management to take stock of current reward practices and take corrective and preventive actions to reduce teacher turnover.

\section{Acknowledgements Competing interests}

The authors declare that they have no financial or personal relationships which may have inappropriately influenced them in writing this article.

\section{Authors' contributions}

This article is based on the Masters study of B.M. (NorthWest University) of which E.N.B. (North-West University) was the supervisor. B.M. compiled the article and E.N.B. provided editorial inputs.

\section{References}

Adedeji, S.O., \& Olaniyan, O. (2011). Improving the conditions of teachers and teaching in rural schools across African countries. Addis Ababa, UNESCO.

Armstrong, A. (2009). Teacher pay in South Africa: How attractive is the teaching profession? Stellenbosch Economic Working Papers: Stellenbosch University.

Armstrong, M. (2007). Employee reward management and practices (2nd edn.). London, UK: Kogan Page Limited.

Armstrong, M., \& Murlis, H. (2007). Reward management. London, UK: Kogan Page Limited.

Avidov-Ungar, O., Friedman, I., \& Ohshtain, E. (2014). Empowerment amongst teachers holding leadership positions. Teachers \& Teaching, 20(6), 704-720. http://dx.doi.org/10.1080/13540602.2014.885706

Baguiley, P. (2009). Performance management (7th edn.). London: Cox and Wyman

Bamberger, M. (2000). Integrating qualitative and quantitative research in development project. Washington, DC: The International Bank for Reconstruction and Development.

Barkhuizen, E.N. (2011). Establishing strategic pay plans. In G. Dessler et al. (Eds.) Human resource management: Global and Southern African perspectives (12th edn., pp. 383-430). Cape Town, Pearson Education.

Barkhuizen, E.N. (2014). Exploring the importance of rewards as a talent management tool for Generation Y employees. Mediterranean Journal of Social Sciences, 5, 1100-1105. http://dx.doi.org/10.5901/mjss.2014.v5n27p1100

Bartlett, C. (2011). Principal succession. Trends and Impacts. Unpublished Doctora dissertation, Faculty of College and Education, University of Houston, Houston, TX.

Beam, B.T., \& Mcfadden, J.J. (2001). Employee benefits. Chicago: Dearborn Financial Publishing Inc

Berger, L., \& Berger, D. (2008). The compensation hand book. London, UK: Macgraw Hill Professional.

Bless, C., Higson-Smith, C., \& Kagee, A. (2006). Fundamentals of social research methods (4th edn.). Cape Town: Juta Co. Ltd.

Briere, D.E., Simonsen, B., Sugai, G., \& Myers, D. (2015). Increasing new teachers' specific praise using a within-school consultation intervention. Journal of Positive Behavior Interventions, 17(1), 50-60. http://dx.doi.org/10.1177/1098300713497098

Bryman, A., \& Bell, E. (2012). Business research method (2nd edn.). New York: Oxford University Press Inc. New Yolk.

Chawla, D., \& Sondhi, N. (2011). Assessing work-life balance among Indian women professionals. Indian Journal of Industrial Relations, 47, 341-352.

Chia-Pin, K., Chin-Chung, T., \& Meilun, S. (2014). Development of a survey to measure self-efficacy and attitudes toward web-based professional development among elementary school teachers. Journal of Educational Technology \& Society, 17 302-315

Christensen, K., \& Schneider, B.L. (2010). Work flexibility-realigning $20^{\text {th }}$ century jobs for a $21^{\text {st }}$ century workforce. New York: Pennsylvania State University Press.

Cooper, D.R., \& Schindler, P.S. (2011). Business research methods (10th edn.). New York: McGraw-Hill Irwin.
Correa, J.A., Parro, F., \& Reyes, L. (2015). Self-selection in the market of teachers. Applied Economics, 47, 1331-1349. http://dx.doi.org/10.1080/00036846.2014.995365

Cresswell, J.W. (2009). Research design: Qualitative, quantitative and mixed methods approaches (3rd edn.). California: Sage Publications.

Davis, M.L., \& Edge, T.J. (2004). Executive compensation. Windsor Professional Information.

Day, C. (2012). New lives of teachers. Teacher Education Quarterly, 39(1), 7-26.

Dieltiens, V., \& Meny-Gibert, S. (2012). In class? Poverty, social exclusion and school access in South Africa. Journal of Education, 55, 128-144.

Disselkamp, L. (2013). Work place asset management book of knowledge. Hoboken, NJ, USA, John Wiley \& Sons Inc.

Du Plessis, A., Carroll, A., \& Gillies, R.M. (2015). Understanding the lived experiences of novice out-of-field teachers in relation to school leadership practices. AsiaPacific Journal of Teacher Education, 43(1), 4-21. http://dx.doi.org/10.1080/13 59866X.2014.937393

Durai, P. (2010). Human resource management. New Delhi: Dorling Kindersley (India) Pvt. Ltd.

Foskett, N., \& Lumby, J. (2002). Leading and managing education - internationa dimension. London: Sage Publication.

Gerhart, B., \& Rynes, S.L. (2003). Compensation. Thousand Oaks, CA: Sage Publications.

Hanhela, T. (2014). The problematic challenges of misrecognition for Pedagogic Action. Educational Philosophy \& Theory: Incorporating ACCESS, 46(1), 59-73. http://dx.doi.org/10.1111/j.1469-5812.2011.00804.x

Hennink, M., Hutter, I., \& Bailey, A. (2011). Qualitative research method. London: Sage Publications Ltd.

Hudson, P. (2012). How can schools support beginning teachers? A call for timely induction and mentoring for effective teaching. Australian Journal of Teacher Education, 37(7), 70-84. http://dx.doi.org/10.14221/ajte.2012v37n7.1

Kappagoda, U.W.M.R., \& Sampath, I.U.P. (2014). Work-family conflict among schoo teachers in North Central Province in Sri Lanka. Journal of Organizational Behavior, 13(3), 53-68.

Khokhar, A.M., \& Zia-ur-Rehman, M. (2014). A study of pay satisfaction and work-tofamily conflict. Compensation \& Benefits Review, 46(3), 177-187. http://dx.doi. org/10.1177/0886368714549932

Krueger, A.B. (2002). Economic consideration and class size, National Bureau of Economic Release working papers. New York: National Bureau of Economic Release Inc.

Leke-ateh, B.A., Assan, T.E.B., \& Debeila, J. (2013). Teaching practice for the 21st century: Challenges and prospects for teacher education in the North-West Province, South Africa. Journal of Social Sciences, 37, 279-291.

Maitland, A., \& Thomson, P. (2011). Future work - how business can adapt and thrive in the new world of work. Hampshire-England: Palgrave Macmillian.

McCleod, D. 2010. The zero turnover sales force. New Yolk: Amacom Books.

Miryala, R.K., \& Chiluka, N. (2012). Work-life balance amongst teachers. Journal of Organizational Behavior, 11(1), 37-50.

Mondy, R.W., Noe, M.R., \& Premeaux, S.R. (2002). Human resource management. London, UK: Prentice Hall.

Monyatsi, P., Steyn, T., \& Kamper, G. (2006). Teacher perceptions of the effectiveness of teacher appraisal in Botswana. South African Journal of Education, 26, 427-441.

Morel, N, (2014). Setting the stage for collaboration: An essential skill for professional growth. Delta Kappa Gamma Bulletin, 81(1), 36-39.

Morse, J.M., \& Niehaus, L. (2009). Mixed methods design: Principles and procedures Volume 4, developing qualitative inquiry. Philadephia, PA: Pennsylvania State University.

Mosoge, M.J., \& Pilane, M.W. (2014). Performance Management: The neglected imperative of accountability systems in education. South African Journal of Education, 34, 1-18. http://dx.doi.org/10.15700/201412120947

Müller, K., Alliata, R., \& Benninghoff, F. (2009). Attracting and retaining teachers: A question of motivation. Educational Management Administration \& Leadership 37, 574-598.

North-West Provincial Legislature. (2013). North West Legislature finds serious challenges in various schools in the province. Mafikeng, South Africa: North-West Provincial Government.

Nthebe, K.J. (2015). The relationship between remuneration, well-being, service quality and the intention to quit of school principals in the North-West Province.
Unpublished Masters thesis, Faculty of Commerce and Administration, NorthUnpublished Masters thesis,
West University, Mafikeng.

Ogunba, E.O., \& Adedeji, S.O. (1986). Infectivity with human ascariasis in Ibadan Oyo State, Nigeria. African Journal of Medicine and Medical Sciences, 15 (3-4), 79-83. State, Nigeria. Afric 3031965.

Olaniyan,

Padma, S., Reddy, M., \& Sudhir, J. (2014). Work-Life Balance and Job Satisfaction Among School Teachers: A Study. Journal of Organizational Behavior, 13(1), 51-60.

Patton, K., \& Parker, M. (2015). 'I learned more at lunchtime': Guideposts for reimagining professional development. The Journal of Physical Education, Recreation \& Dance, 86(1), 23-29. http://dx.doi.org/10.1080/07303084.2014.978421

Pianta, R.C., De Coster, J., Cabell, S., Burchinal, M., Hamre, B.K., Downer, J., et al. (2014). Dose-response relations between preschool teachers' exposure to components of professional development and increases in quality of their interactions with children. Early Childhood Research Quarterly, 29(4), 499-508. $\mathrm{http}: / / \mathrm{dx}$.doi.org/10.1016/j.ecresq.2014.06.001 
Pring, R. (2004). Philosophy of educational research (2nd edn.). New Yolk: Continuum Books.

Qureshi, S. (2015). Teaching fellowships for UK foundation doctors. Medical Teacher 37(1), 90-91. PMID: 25073019, http://dx.doi.org/10.3109/0142159X.2014.916781

Reddick, C.G., \& Coggburn, J.D. (2008). Hand Book of Employee Benefits and Administration. New York, NY: CRC Press Taylor \& Francis Group.

Rothstein, J. (2015). Teacher quality policy when supply matters. American Economic Review, 105(1), 100-130.

Ruchi, T., \& Justin, P. (2014). Determinants of attitude of teachers - Factor analysis and strategies for success. Competitiveness Review, 24(1), 5-19. http://dx.doi. org/10.1108/CR-08-2013-0070

Saunders, M., Lewis, P., \& Thornhill, A. (2007). Research methods for business students (4th edn.). Edinburgh Gate, Essex, UK: Pearson.

Schlechter, A., Faught C., \& Bussin, M. (2014). Total rewards: A study of artisan attraction and retention within a South African context. SA Journal of Human Resource Management/SA Tydskrif vir Menslikehulpbronbestuur, 12(1), 1-15. http://dx.doi.org/10.4102/sajhrm.v12i1.648

Schullion, H. (2011). Global talent management. New York: Taylor \& Francis.

Schwab, K. (2015). The Global Competitiveness Report 2014-2015. World Economic Forum.

Shukia, R. (2009). Talent management process of developing and integrating skilled workers. New Delhi: Global India Publication, Pvt Ltd.

Smith, J., Conley, S., \& You, S. (2015). Perceptions of retirement affect career commitment: The mediating role of retirement system satisfaction for two teacher age groups. Educational Gerontology, 41, 267-281. http://dx.doi.org/10. 1080/03601277.2014.958018

Smithe, J.W., \& London, M. (2009). Performance management: Putting research into action. New York: Amacom Books.

South African Council for Educators. (2010). A review of teacher demand and supply: Identifying research gaps and the role of SACE. Pretoria, SACE.

Steinberg, M.P. (2014). Does Greater Autonomy Improve School Performance? Evidence from a Regression Discontinuity Analysis in Chicago. Education Finance and Policy, 9(1), 1-35. http://dx.doi.org/10.1162/EDFP_a_00118
Stempien, L.R., \& Loeb, R.C. (2002). Differences in job satisfaction between general education and special education teachers: Implications for retention. Remedia and Special Education, 23(5), 258-267.

Steyn, T. (2013). Professional and organisational socialisation during leadership succession of a school principal: A narrative inquiry using visual ethnography. South African Journal of Education, 33(2), 1-17.

Strauss, M. (2012). Exploring the factors for attracting and retaining teachers to rural areas. Unpublished Master's dissertation. Pretoria: Faculty of Economic and Management Sciences, University of Pretoria.

Thyme, K.E., Wiberg, B., Lundman, B., \& Graneham, U.H. (2013). Qualitative content analysis in art psychotherapy research: Concepts, procedures, and measures to reveal the latent meaning in pictures and the words attached to the pictures. The Arts in Psychotherapy, 40, 101-107. http://dx.doi.org/10.1016/j. aip.2012.11.007

Tracy, S.G. (2013). Qualitative research method. West Sussex: John Willey \& Sons Ltd.

Tuytens, M., \& Devos, G. (2012). Importance of system and leadership in performance appraisal. Personnel Review, 41(6), 756-776. http://dx.doi. org/10.1108/00483481211263692

Van der Berg, S., \& Burger, R. (2010). Teacher pay in South Africa. Stellenbosch Economic Working Papers. Department of Economics and Bureau for Economic Research, Stellenbosch University.

Vorster, D. \& Barkhuizen, E.N. (2013). Social Capital as a Predictor of Work Wellness of Academic Staff. In N. Delener, L. Fuxman, F. Lu, S. Rodrigues, \& L. Rivera (Eds.), 15th Annual International Conference on Globalizing Businesses for the Next Century: Visualizing and Developing Contemporary Approaches to Harness Future Century: Visualizing and Developing Contemporary Approaches to Harness Future
Opportunities, Global Business and Technology Association, Helsinki, Finland Opportunities, Global Business
(pp. 1271-1277). USA, Gbata.

Williams, C., Champion, T., \& Hall, I. (2012). MGMT Canadian Ed. USA: Nelson Education Ltd.

World at Work Model (2011). Total Reward Model. Washington DC: World-Wide Headquarters World at Work. Retrieved October 12, 2014, from http://www. worldatwork.org/home $/ \mathrm{ht} / \mathrm{m} / \mathrm{home} / \mathrm{jsp}$ 2010: United State of America, Washington D.C.13/04/2014

Yin, R.K. (2012). Applications of case study research (3rd edn.). Thousand Oaks, CA: SAGE Publications, Inc. 